Conner, R. L., van Wagtendonk, W. J. \& Miller, C. A. (1953). J. gen. Microbiol. 9, 434-439.

\title{
The Isolation from Lemon Juice of a Growth Factor of Steroid Nature required for the Growth of a Strain of Paramecium aurelia
}

\author{
BY R. L. CONNER,* W. J. vAN WAGTENDONK \\ AND C. A. MILLER \\ Department of Zoology, Indiana University, Bloomington, Indiana, U.S.A.
}

SUMMARY: A steroid fraction obtained from lemon juice was found to be an essential metabolite for Paramecium aurelia, var. 4, stock 51.7 (s), in axenic culture. This steroid is closely related to, or is identical with, either $\beta$-sitosterol or $\gamma$-sitosterol.

Paramecium aurelia has been established in pure culture in a heat-sterilized medium, composed of equal parts of a $0.5 \%$ yeast autolysate (Basamin-Busch) and a $24 \mathrm{hr}$. culture of Aerobacter aerogenes in lettuce extract (van Wagtendonk \& Hackett, 1949). Lettuce or other plant extracts were shown to be essential since no growth of $\boldsymbol{P}$. aurelia could be obtained when these extracts were omitted. An axenic medium, consisting of a salt solution, dialysed yeast extract, a solution of water-soluble vitamins, proteose peptone, and guanylic and cytidilic acid has been developed (van Wagtendonk, Miller \& Conner, 1952; van Wagtendonk, Conner, Miller \& Rao, 1953). P. aurelia is unable to grow in this medium unless plant extracts are added. An essential metabolite for $\boldsymbol{P}$. aurelia must therefore be present in plants. The isolation and identification of this metabolite is described.

\section{EXPERIMENTAL \\ Method of assay}

P. aurelia, variety 4, stock 51.7, sensitive (Sonneborn, 1949) is not able to grow in either axenic or bacterized media in the absence of plant extracts. Rapid screening assays for activity are desirable in an extraction of biologically active material. The test in axenic medium is slow, and for this reason fractions were screened using a bacterized medium. The basal medium for the bacterial assay consisted of: $\mathrm{NaCl}, 0.3 \mathrm{~g}$; $\mathrm{KCl}, 0.05$ g.; $\mathrm{Na}_{2} \mathrm{HPO}_{4}$, 0.1 g.; $\mathrm{NaH}_{2} \mathrm{PO}_{4}, 0.1$ g.; $\mathrm{CaCl}_{2} .2 \mathrm{H}_{2} \mathrm{O}, 0.05$ g.; $\mathrm{MgSO}_{4} .7 \mathrm{H}_{2} \mathrm{O}, 0.01$ g.; $\mathrm{FeSO}_{4}\left(\mathrm{NH}_{4}\right)_{2} \mathrm{SO}_{4} \cdot 24 \mathrm{H}_{2} \mathrm{O}, 0 \cdot 125 \mathrm{~g}$.; double distilled water, 1 l.; $\mathrm{HCl}$ to $\mathrm{pH} \mathrm{6.5}$.

The extracts to be tested were prepared in serial dilutions, using the salt solution as a diluent. These dilutions were autoclaved at $120^{\circ}$ for $15 \mathrm{~min}$. They were then inoculated with $A$. aerogenes $24 \mathrm{hr}$. before use for the assay, as in the procedure routinely used for the culture of $\boldsymbol{P}$. aurelia (Sonneborn, 1950).

* Predoctoral Fellow of the National Science Foundation. 
One-half $\mathrm{ml}$. of each dilution of the fractions being tested was placed in each depression of a 8-depression slide. Single isolations of $\boldsymbol{P}$. aurelia were placed in each depression, and the depressions incubated at $27^{\circ}$. After $24 \mathrm{hr}$. the number of animals present in each depression was counted and a single isolation from each depression was made into fresh culture fluid of the same composition. This was repeated three times. In each series a control, consisting of the basal medium with $A$. aerogenes alone, was included. No multiplication of $\boldsymbol{P}$. aurelia took place in these controls, except during the first $24 \mathrm{hr}$.

In order to express quantitatively the activities of the different fractions as measured in the bacterized medium, it was necessary to adopt a unit of activity. One unit was arbitrarily defined as follows: a solution of an active fraction contains one unit when $P$. aurelia, var. 4, stock 51.7 (s), transferred to the medium, will undergo at least three fissions per day on three consecutive transfers of a single animal.

The highly purified fractions were tested qualitatively in an axenic medium prepared as follows: One pound of Fleischmann's bakers' yeast was finely crumbled and dried at $65^{\circ}$. A $1: 4(w / v)$ suspension of the dried yeast was prepared by continuously stirring the yeast in distilled water at $60^{\circ}$ for $3 \mathrm{hr}$. The suspension was autoclaved for $20 \mathrm{~min}$. at $120^{\circ}$, centrifuged, and filtered through a Seitz filter pad (no. 8) for sterilization and clarification. A 1\% solution of proteose peptone (Difco) was made in distilled water and autoclaved for $20 \mathrm{~min}$. at $120^{\circ}$. One volume of the yeast extract was added aseptically to 5 vol. of the proteose peptone solution. In this medium the factor from plant extracts is the limiting component. The fractions were made up in double distilled water in the optimal concentration as determined by the bacterial assay method. Such a fraction was considered to be active when $\boldsymbol{P}$. aurelia, transferred to this medium, showed sustained growth for at least four consecutive transfers. This assay served to eliminate the possibility that the factor from lemon juice was altered by the bacteria and thereby made available to $\boldsymbol{P}$. aurelia.

After the factor had been obtained in the crystalline state and identified as a steroid, direct comparisons between the population densities obtained with other steroids were possible. Serial dilutions of the factor and of the steroids were made in the following manner: a weighed amount was dissolved in $95 \%$ ethanol, so that the resulting solution contained $1 \mathrm{mg} . / \mathrm{ml}$. This solution was then added by means of a fine pipette to double distilled water heated to $70^{\circ}$; this resulted in the formation of a stable suspension. The final concentration of all compounds so prepared was $100 \mu \mathrm{g} . / \mathrm{ml}$. Further serial dilutions were made with distilled water. The tubes were then autoclaved. Desired amounts of these dilutions were added aseptically to the axenic medium described above. Approximately thirty animals were inoculated into each tube and incubated for 4 days at $27^{\circ}$. After four such transfers the number of animals/ $\mathrm{ml}$. in each tube was determined by counting the number of organisms present in suitable samples. (Nephelometric techniques could not be applied because of intense light scattering by the organisms.) Except for the first transfer, 


\section{R. L. Conner, W. J. van Wagtendonk and C. A. Miller}

no multiplication of $\boldsymbol{P}$. aurelia took place in the absence of the factor from lemon juice. All concentrations were tested in duplicate and every assay was repeated at least three times.

\section{Distribution of the growth factor}

Various plant and animal sources were tested for growth-promoting activity. The results are given in Table 1. No preparations from animal sources were active. It is not known whether the activity displayed by the different plant extracts is due to the same factor. Lemon concentrate was the most active source and was selected for the extraction and purification of the growth factor.

Table 1. Relative activity of various raw materials

Cerophyl extract*
Water extract of desiccated lettuce (Difco)
Water extract of baked lettuce
Orange juice (fresh)
Lemon juice (fresh)
Lemon concentrate
Lemon peel infusion $\dagger$
Wilson liver extract
Proteose peptone
Bacto tryptone
Casamino acids

Relative
activity
$\mathbf{1}$
$\mathbf{3}$
$\mathbf{4}$
$\mathbf{1 0}$
$\mathbf{1 5}$
$\mathbf{6 0}$
$\mathbf{0}$
$\mathbf{0}$
$\mathbf{0}$
$\mathbf{0}$
$\mathbf{0}$

* Obtained from the Cerophyl Laboratories through the courtesy of Dr G. A. Köhler. + Obtained from the California Fruit Growers Exchange through the courtesy of Dr W. E. Baier.

Extraction and purification of the growth factor from lemon juice

The extraction procedure included the following steps: (1) precipitation of the active fraction with acetone; (2) extraction of the precipitate with hot ethanol; (3) saponification of the extract with methanolic KOH; (4) phase distribution; (5) chromatography. Steps 1-4 are given in Table 2, and step 5 in Table 3. In the first two steps, the precipitation and the extraction of the precipitation with hot ethanol, the total activity increased, presumably caused by the removal of inhibitory substances. The saponification of the ethanolic extract resulted in a large increase in potency/ $\mu \mathrm{g}$., as does the following phase distribution.

Three distinct bands appear in the chromatogram (Table 3). Most of the activity is present in the second band. After elution with hot ethanol a yellow solution was obtained from which white crystals separated after cooling to $-10^{\circ}$. The inactive yellow material was removed by repeated recrystallization from $95 \%$ ethanol at $4^{\circ}$. A pure compound, representing $0.025 \%$ of the original solids and $20 \%$ of the original activity, was isolated. The chemical characteristics of this compound are given in Table 4.

The infra-red spectrum of the growth factor for $P$. aurelia is very similar to that of a sample of $\beta$-sitosterol (Fig. 1). 
Table 2. Precipitation, extraction, and phase distribution steps for the purification of the growth factor for Paramecium aurelia, var. 4, stock $51.7(s)$

The yields and activities are based on assays with the bacterized medium.

\section{Treatment}

1 gal. of lemon concentrate, chill to $4^{\circ}$ and add equal volume of cold acetone, stir well and centrifuge at $1000 \mathrm{~g}$ at $4^{\circ}$ (supernatant solution, inactive)

\section{Precipitate}

Suspend $P_{1}$ in hot $95 \%$ ethanol $(500 \mathrm{ml}$.), stir, filter while hot. Repeat 3 times, combine extract (residue inactive) and concentrate to solids

Dissolve $\mathrm{E}$ in $500 \mathrm{ml}$. of hot $80 \%$ methanolic KOH (10\%). Allow to stand for $4 \mathrm{hr}$. with occasional shaking. Extract 3 times with $200 \mathrm{ml}$. petroleum ether $\left(30-60^{\circ}\right)$. Combine petroleum ether extracts and concentrate to solids

Methanol layer of $\mathbf{E}$

Dissolve $R$ in $100 \mathrm{ml} .80 \%$ methanol and extract 3 times with $\mathrm{CCl}_{4}$. Dry with anhydrous $\mathrm{MgSO}_{4}$, filter and concentrate in vacuo

Methanol layer of $\mathbf{R}$

\begin{tabular}{|c|c|c|c|}
\hline Fraction & $\begin{array}{c}\text { Solids } \\
(\%)\end{array}$ & $\begin{array}{c}\text { Activity } \\
(\%)\end{array}$ & $\begin{array}{l}\text { Potency } \\
\text { units } / \mu \mathrm{g} .\end{array}$ \\
\hline 1 & 100 & 100 & $0 \cdot 125$ \\
\hline 2 & 37 & 150 & 0.5 \\
\hline $\mathbf{3}$ & 7 & 170 & 8 \\
\hline 4 & $0 \cdot 6$ & 96 & 20 \\
\hline 5 & $6 \cdot 4$ & $\mathbf{3}$ & 0.5 \\
\hline 6 & $0 \cdot 3$ & 96 & 40 \\
\hline 7 & 0.3 & 2 & 10 \\
\hline
\end{tabular}

Table 3. Alumina column step in the purification for the growth factor for Paramecium aurelia, var. 4, stock 51.7 $(s)$

$4.5 \mathrm{~g}$. of fraction 6 (Table 2) was dissolved in $25 \mathrm{ml}$. $\mathrm{CCl}_{4} .5 \mathrm{ml}$. portions were added to columns $(1.5 \times 10 \mathrm{~cm}$.) of $12 \mathrm{~g}$. cyanide-treated, acetic-acid-washed alumina (Eli Lilly and Co., Indianapolis, Indiana. Lot number 190-4B-292). The column was washed with $25 \mathrm{ml}$. $\mathrm{CCl}_{4}$ and developed with $\mathrm{CCl}_{4}$-ethyl ether $(\boldsymbol{\theta} \cdot 1)$ till 8 bands separated. A total of $25 \mathrm{ml}$. of the developer was used. The column was cut in three portions corresponding to the bands, and each portion was eluted with hot ethanol. The combined fractions of five such chromatograms were combined and evaporated in vacuo to solids.

\begin{tabular}{|c|c|c|c|c|c|}
\hline $\begin{array}{c}\text { Band } \\
\text { no. }\end{array}$ & Colour & Fraction & $\begin{array}{c}\text { Solids } \\
(\%)\end{array}$ & $\begin{array}{c}\text { Activity } \\
\text { (\%) }\end{array}$ & $\begin{array}{l}\text { Potency } \\
\text { units } / \mu \mathrm{g} .\end{array}$ \\
\hline $\mathbf{1}$ & Bright yellow & $\mathbf{D}_{1}$ & 0.05 & 0 & $\mathbf{0}$ \\
\hline $\mathbf{2}$ & Deep orange & $\mathrm{D}_{2}$ & 0.20 & 107 & 67 \\
\hline $\mathbf{3}$ & Light yellow & $\mathrm{D}_{3}$ & 0.05 & $0 \cdot 4$ & 10 \\
\hline
\end{tabular}

Table 4. Chemical characteristics of the factor from lemon juice

Melting point $136 \cdot 5-137 \cdot 5^{\circ}$ (uncorrected).

Carbon and hydrogen analysis.

C H

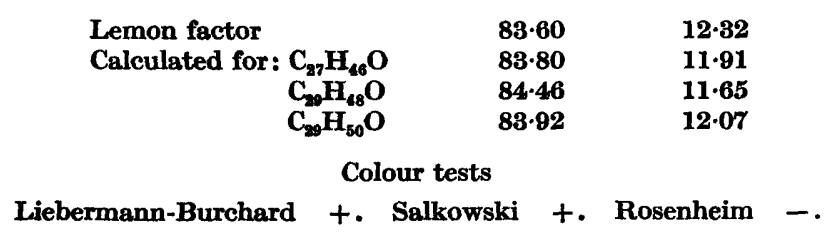


438 R. L. Conner, W. J. van Wagtendonk and C. A. Miller

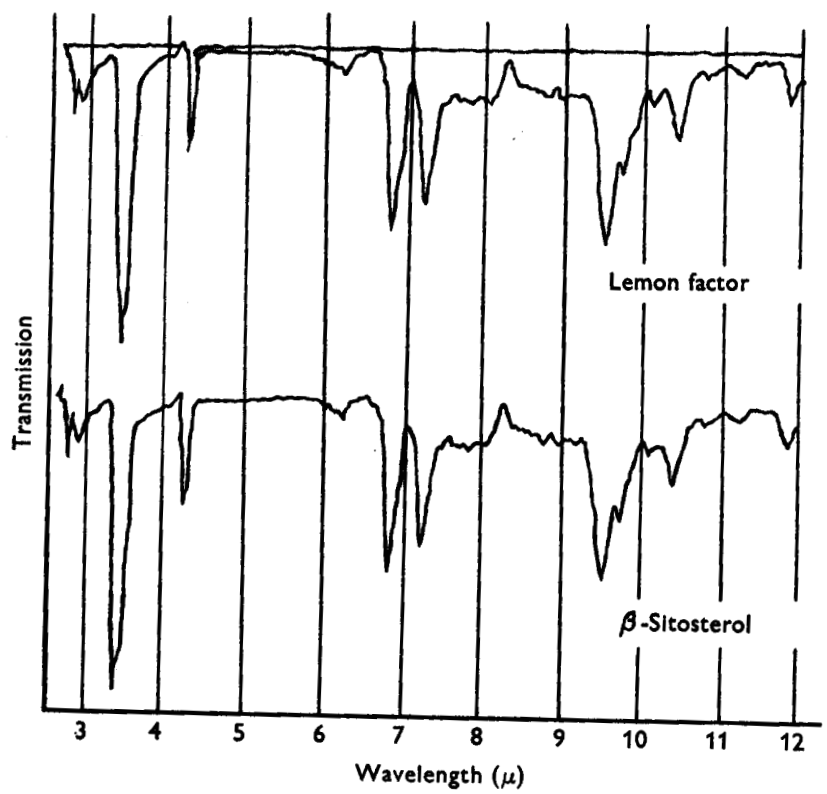

Fig. 1. Infra-red adsorption curves of the steroid from lemon juice and of $\beta$-sitosterol. The curves are tracings from original automatic recordings. Second curve: steroid from lemon juice (Paramecium factor), $11.0 \%$ in chloroform. Third curve: $\beta$-sitosterol, $11.8 \%$ in chloroform. Chloroform (first curve) was passed over $\mathrm{SiO}_{2}$ and $\mathrm{Al}_{2} \mathrm{O}_{3}$ to remove traces of water and alcohol.

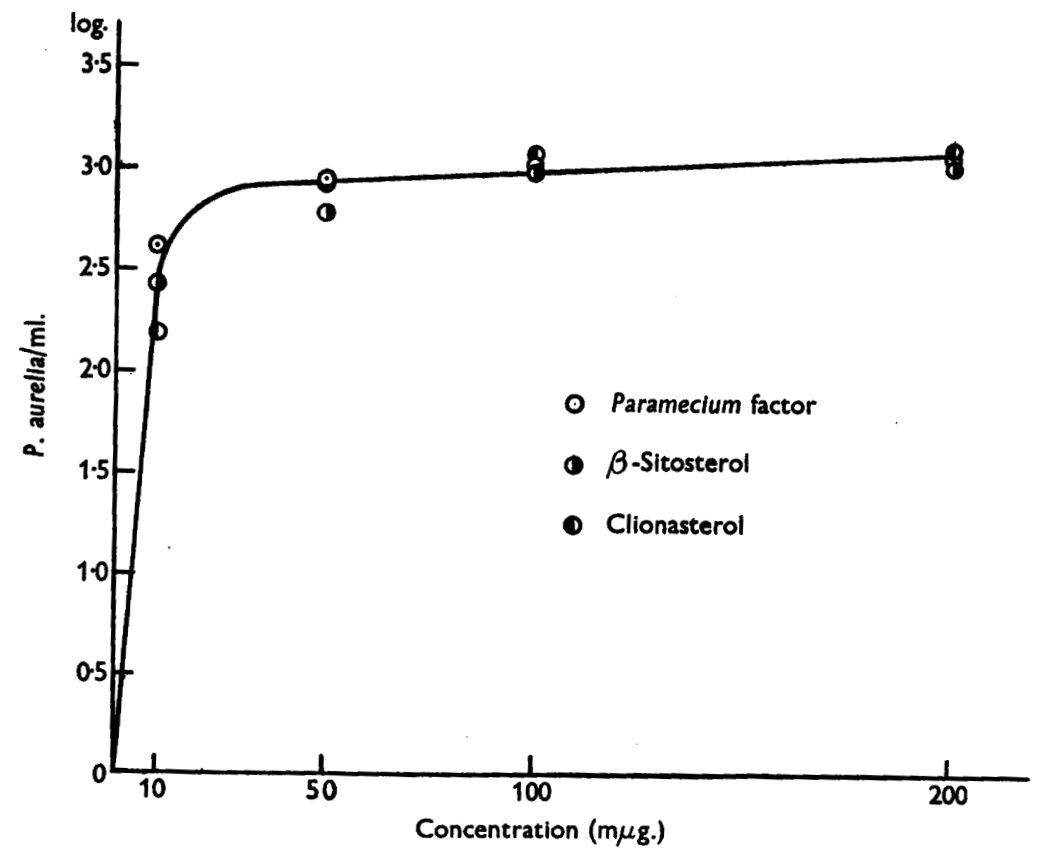

Fig. 2. Growth response of Paramecium aurelia, var. 4, stock 51.7 (s), in axenic culture to increasing concentrations of the steroid, isolated from lemon juice, $\beta$-sitosterol and clionasterol. 
The growth-promoting activity of the factor from lemon juice was compared with that of $\beta$-sitosterol and clionasterol (inferred to be the 24a-epimer of $\beta$-sitosterol (Bergmann \& Low, 1947; Fieser \& Fieser, 1949)). It can be seen from Fig. 2, that the three compounds have very similar growthpromoting activities.

Because of (1) the close similarity of the infra-red spectra of the factor from lemon juice and $\beta$-sitosterol, and (2) the fact that the factor from lemon juice, $\beta$-sitosterol and clionasterol have similar growth-promoting activities, it is tentatively concluded that the growth factor for $\boldsymbol{P}$. aurelia, var. 4, stock $51.7(\mathrm{~s})$, is closely related to, or identical with, either $\beta$ - or $\gamma$-sitosterol. The possibility is not excluded that the fraction isolated from lemon juice is a mixture of these two isomers.

We wish to thank Dr W. E. Baier (California Fruit Growers Exchange) for generous supplies of lemon concentrate, $\mathrm{Dr}$ W. Bergmann for samples of various steroids, and Dr A. van Abeele and Dr H. Boaz (Eli Lilly and Co.) for their cooperation in performing the $\mathrm{C}, \mathrm{H}$ analyses and infra-red adsorption spectra. This .work was carried out under a contract between Indiana University and the Office of Naval Research (Contract no. $60 \mathrm{nr}-18010$ ). It was also supported by grants from the Rockefeller Foundation and Indiana University.

This paper is contribution no. $\mathbf{4 7 8}$ from the Department of Zoology, Indiana University.

\section{REFERENCES}

Beramann, W. \& Low, E. M. (1947). Contributions to the study of marine products. $\mathrm{XX}$. Remarks concerning the structure of sterols from marine invertebrates. J. org. Chem. 67.

Fieser, L. F. \& Finser, M. (1949). Natural Products Related to Phenanthrene, 3rd ed. New York: Reinhold Publishing Corporation.

Sonneborn, T. M. (1949). Beyond the gene. Amer. Scient. 37, 33.

Sonneborn, T. M. (1950). Methods in the general biology and genetics of Paramecium aurelia. J. exp. Zool. 113, 87.

Wagtendonk, W.J. van \& HACKetT, P. L. (1949). The culture of Paramecium aurelia in the absence of other living organisms. Proc. nat. Acad. Sci., Wash. 35, 155.

Wagtendonk, W. J. van, Mruler, C. A. \& Conner, R. L. (1952). Growth requirements of Paramecium aurelia, var. 4, stock 51.7 (s), in a medium free of other living organisms. Fed. Proc. 11, 302.

Wagtendonk, W. J. van, Conner, R. L., Miluer, C. A. \& Rao, M. R. R. (1953). Growth requirements of Paramecium aurelia, var. 4, stock 51, sensitives and killers, in axenic medium. Ann. N.Y. Acad. Sci. (in the Press).

(Received 18 May 1953) 